\title{
SPIN-OFF DECISION MAKING IN ISLAMIC WINDOWS OF FINANCING COMPANIES
}

\author{
Intan Herlina Oktaviani, Muhammad Budi Prasetyo* \\ Faculty of Economic and Business, Universitas Indonesia, Indonesia
}

\section{Citation (APA 7th): Oktaviani, I. H., \& Prasetyo, M. B. (2021). Spin-off Decision Making in Islamic Windows of Financing Companies. Jurnal Minds: Manajemen Ide Dan Inspirasi, 8(2), 191-208. \\ https://doi.org/10.24252/minds .v8i2.21902 \\ Submitted: 6 July 2021 \\ Revised: 26 \& 29 July 2021 \\ Accepted: 09 August 2021 \\ Published: 21 September 2021 \\ Copyright: (C) 2021 by the authors.}

\begin{abstract}
Decision-makers must consider many factors in carrying spin-off. The previous literature discussed more results on academics, non-financial companies, or Islamic banking. This paper proposes essential criteria to use in the analysis of financing company spin-off decisions. This article uses the AHP method by distributing questionnaires to the Directors of financing companies entitled to make spin-off decisions to determine the priority of the criteria and sub-criteria in question. The results show that financial condition is an essential criterion in making spin-off decisions. As for the Islamic financing business concept and strategy, the rate of return and growth are the top ranks for the subcriteria chosen by the spin-off decision-maker.
\end{abstract}

Keywords: AHP; Decision Making; Financing Company; Islamic Finance; Spin-off

*Corresponding Author : $\underline{\text { m.budi.prasetyo@ui.ac.id }}$

DOI: $10.24252 /$ minds.v8i2.21902

ISSN-E: 2597-6990

ISSN-P: 2442-4951

http://journal.uin-alauddin.ac.id/index.php/minds

Publisher: Program Studi Manajemen, Universitas Islam Negeri Alauddin Makassar 


\section{INTRODUCTION}

The development of the Islamic Financing Company industry in the last three years has declined sharply. The decline in financing assets and receivables in this industry occurred due to several factors, namely the Financing to Value (FTV) policy that did not differ between conventional and Islamic. The sluggish condition of the vehicle industry and the company's internal policies that did not favor the development of Islamic financing are also other factors. The decline also occurred in the number of entities in the Islamic finance company industry. Statistical data released by OJK showed a decrease in Islamic windows by almost $30 \%$, from 41 companies in 2014 to 28 companies in 2020.

This negative growth that lasted for a long time made OJK make several regulatory changes to stimulate the industry to get excited again. One of the regulatory changes made by $\mathrm{OJK}$ is the regulation regarding the obligation to separate Islamic windows from Financing Companies, which containing in POJK number 28/POJK.05/2014 concerning Business Licensing and Institutional Financing Companies and Islamic Financing Companies (POJK 28). Article 37 paragraph (1) of the regulation mandates financing companies that have Islamic windows to separate if the Islamic windows asset value has reached at least $50 \%$ (fifty percent) of the total assets of the parent Financing company or a maximum of 5 (five) years since the enactment of the regulation or November 2019. The provisions regarding the deadline for the separation of Islamic windows are considered difficult for finance companies. OJK later replaced the law with the POJK number 47/POJK.05/2020 regarding Business Licensing and Institutional Financing Companies and Islamic Financing Companies (POJK 47). In the said regulation, OJK has eliminated the provision regarding spin-off obligations. Thus, finance companies have the authority to determine how they control the Islamic business in their respective companies and when they want to dispose of the business to stand alone.

On the other hand, the government and the public still want to establish a healthy Islamic financing company to significantly contribute to the Indonesian economy (Otoritas Jasa Keuangan, 2021). Therefore, the decision to spin-off the Islamic windows Financing Company becomes very crucial. The Islamic window that will be spin-off is expected to be ready to become an independent company. And Islamic window that is ready should carry out a spin-off. A study is needed that can be used to determine which Islamic window is prepared. However, there is no scientific and reasonable quantitative method to compare the various options and choose the optimal solution.

The previous literature discussed more spin-offs on academics, nonfinancial companies, or Islamic banking. Research in Islamic banking conducted by Al Arif et al. (2017) found that the impact of spin-offs was not felt on assets and deposit funds. However, total financing was found to increase significantly. The study also states that it is implausible that Islamic banks in Indonesia can reach $50 \%$ of the parent bank's assets. However, Al Arif (2018) proved that spin-

offs have an excellent effect on savings. He also observed the relationship between spin-offs and market share (Al Arif, 2017) and spin-offs efficiently (Al 
Arif et al., 2018). However, these researches do not observe the spin-off process that occurs in the Financing Company.

The purpose of determining the spin-off policy in research on Islamic banking, according to Al Arif et al. (2017), among others, is (1) increasing the growth of the Islamic banking industry so that it can make a significant contribution to the Indonesian economy, (2) increasing the independence of bank subsidiaries, (3) improving the performance of the resulting bank spin-offs, and (4) increasing the compliance of Islamic banks with Islamic principles. Likewise for other Islamic financial service institutions, including Islamic finance companies. A particular study is needed on the spin-offs of Islamic finance companies in Indonesia, given the critical objective and lack of research. The lack of data on Islamic finance companies has resulted in the discussion of spin-offs in finance companies becoming less attractive even though this issue is considered essential. Spin-off arrangements significantly affect developing Islamic finance (Fernando, 2018; Sari, 2019).

Spin-off decision-making is a complex and unstructured decision. The Analytical Hierarchy Process (AHP) can be used to build a multi-criteria decision-making model that takes this into account. AHP can be used in research on strategic decision-making such as mergers, acquisitions, and joint ventures. Cevik Onar et al. (2014) used AHP to determine the weight of the determinants of the unification, acquisition, and joint venture decisions. The research is used in international electronics companies. AHP is also applied in exploring various challenges during post-merger integration in real estate companies (Al Hosani \& Jabeen, 2019). The AHP method is also used to inspect two infrastructure PPP projects and elaborate on the characteristics of PPP projects in China (Liang \& $\mathrm{Hu}, 2020)$. A spin-off is a strategic decision like mergers and acquisitions. Decision-makers must consider many factors in carrying out this move.

There has been no analysis to determine the determinants that influence the decision-making of the Islamic windows spin-off. To assist in making a spinoff decision on Islamic windows of finance companies, the questions asked in this study are what are the influencing factors, and how do these factors influence decision making? In addition, this study also discusses steps that regulators can take to help speed up the spin-off preparation process. So later, this research can benefit the company's top-level management recognize and prepare themselves in the spin-off preparation process and provide information enrichment to academics regarding the condition of finance companies in carrying out spinoffs.

\section{THEORETICAL REVIEW}

\section{Financing Company}

Definition of a Financing Company according to POJK Number 35/POJK.05/2018 concerning Business Implementation of Financing Companies (POJK 35), POJK Number 10/POJK.05/2019 concerning Business Implementation of Islamic Financing Companies and Islamic windows of Financing Companies 
(POJK 10) and POJK Number 47/POJK.05/2020 concerning Business Licensing and Institutional Financing Companies and Islamic Financing Companies (POJK 47) are business entities that finance goods and services. Meanwhile, according to Soemitra (2017), finance companies as business entities included in the business sector of Financing Institutions can provide facilities to people who want to obtain an asset that can provide added value to them using borrowing or financing schemes.

In other countries, they have known as leasing companies, consumer finance company or credit-specialized company. In China, a licensed consumer finance company is a non-banking financial institution that has been approved by the China Banking and Insurance Regulatory Commission (Liu, 2020). Leasing companies in Russia provide financing for motor vehicles, special equipment, and other segments (Vovchenko et al., 2018). While in South Korea, they have been known as specialized credit finance business companies (Kim \& Oh, 2020).

Islamic Financing Companies according to POJK Number 31/POJK.05/2014 concerning the Implementation of Islamic Financing Businesses (POJK 31), which were later changed to POJK 10, are Financing Companies whose entire business activities carry out Islamic financing. Islamic financing is financing made based on an agreement or agreement between a finance company and its consumers. The consumer is obliged to return the funding within the agreed period with compensation or profit-sharing (Soemitra, 2017).

\section{Corporate Spin-Off}

Growing companies need to expand their business activities by seeking new markets by offering new products and services or competing in different geographies. Corporate strategy is a decision made by senior management and action based on objectives taken to gain a competitive advantage in several industries and markets simultaneously (Rothaermel, 2017). Companies can achieve growth with three options: organic growth through internal development, external growth through alliances, or external growth through acquisitions.

Sometimes companies have to refocus both on internal development and external growth that the company has done. For this reason, the company can use an exit strategy such as divestment or spin-off. DePamphilis (2019) states that a spin-off is a stock dividend paid by a company to its current shareholders consisting of shares in an existing or newly created subsidiary. In this definition, DePamphilis (2019) states that the spin-off does not provide the parent company with cash inflows. So this is different from other exit strategies such as divestment and equity carve-out. Ito (1995) argues differences in principle between the spin-offs in the United States and Japan. Ito (1995) describes a spinoff as partially owned by the parent company but managed independently and may be listed on the stock market. Partial ownership here means varying degrees of an ongoing relationship between the parent company and the spin-off company. The parent company's level of control over the spin-off company depends on various circumstances based on strategy, finance, and human 
resources. Although the objectives are different, both types of spin-offs share the same responsibility for the parent company to independently make spin-off decisions for appropriate divisions.

DePamphilis (2019) categorizes spin-offs into exit strategies that can be carried out by company management. The reasons for the company's plan to optout of certain businesses include (1) increasing the company's focus, (2) businesses that perform poorly, (3) in the attention of regulators, (4) incompatibility, (5) tax problems, (6) fundraising, (7) more value to others, (8) risk reduction, (9) Eliminate unwanted business from previous acquisitions, (10) avoid conflicts with consumers, and (11) increase transparency. In addition to the motives for existing businesses discussed earlier, DePamphilis (2019) also states that spin-offs provide a means to reward shareholders in the form of nontaxable dividends (if properly structured). With its independence from its parent, the spin-off unit can focus on its growth strategy without interference from the parent company's BOD, who may not fully understand the unit's operations. Spin-offs are also an easy alternative to letting go of a hard-to-sell business. Firms may take sequential spin-offs and acquisitions to gain ongoing synergies and restore the allocation of managerial attention within their organizations (Bennett \& Feldman, 2017). Spin-offs also significantly impact the share prices of the parent firm (Aggarwal \& Garg, 2019).

The success of the spin-off is also examined from the side of the human resources associated with these activities. The intensity and variety of interactions between prospective entrepreneurs and other individual actors positively impact spin-off performance at incubation and emergence stages (Furlan \& Grandinetti, 2014). While finding and explaining the spin-off of business model transfer, Li et al. (2020) find that the independent operation is the successful guarantee of the spin-off of business model transfer. Research on spinoffs in group companies found that spin-off performance was significantly correlated with the number of CEO tenures at the parent company, as well as the company's founding method, the company's technology sources, and the number of items jointly owned by the parent company (Chu et al., 2010).

As a newly established company, the spin-off company needs IT support as it used to before the new company was formed. One thing that can be done is the transfer of technology from the parent company. According to Rogers et al. (2001), the technology transfer process is a type of communication that is not easy and requires skilled and agile personnel, adequate resources, and other rewards/incentive structures. For this reason, IT support is an essential factor that must be prepared before carrying out the spin-off. In another study, human resources, especially business leaders, negatively influence spin-off policies, so companies are recommended to train new leaders if they are going to reorient business units to become independent companies (Leitner et al., 2021).

The decision to externalize a business unit from a company is driven primarily by short-term benefits, possible risks, and synergies (Pizarro-Moreno et al., 2021). Esch et al. (2019) find that an integrated information basis leads to supreme sustainable value creation decisions. And for the information set up for 
external reporting can also be utilized for internal purposes to help companies build sustainable decision behavior.

These criteria also represent the decision-making criteria in the spin-off. In addition to these criteria, it is essential to pay attention to the attention of shareholders and decision-makers in financing companies on Islamic windows and the strategies they will carry out to develop Islamic windows in the future (Roosmawati, 2021). Decision-making must consider the growth during the establishment of Islamic windows and the potential faced in the future.

\section{Spin-Off In Islamic Finance Industry}

The separation of Islamic windows (spin-off Islamic windows) of finance companies is regulated for the first time in OJK Regulation number 28/POJK.05/2014 concerning Licensing and Institutional Financing Companies. According to the regulation, the deadline for the spin-off obligation is 5 (five) years from its stipulation in November 2014, namely in November 2019. However, the effect of this regulation, especially in 2018, made finance companies withhold the performance of their Islamic unit to set strategies when a spin-off was required in 2019, as stated by the General Chairperson of the Association of Financing Companies (APPI) Suwandi Wiratno. The 'wait and see' action was taken because the finance company still had doubts about developing its Islamic windows or not (Fernando, 2018; Sari, 2019).

From the latest developments, the regulation was later amended to reelevate the performance of Islamic Financing Companies. There are no criteria for the obligation to separate Islamic windows from an Islamic Financing Company in POJK 47 of 2020 as a substitute for POJK 28 of 2014. In the absence of a spin-off obligation deadline, the strategy for separating Islamic windows from a Financing Company is voluntary, without any obligation or coercion from regulations. So the Financing Company needs its assessment scheme to determine whether Islamic windows is ready for a spin-off.

Research on spin-offs in the Islamic finance industry discusses Islamic banking more. The purpose of determining the spin-off policy, according to $\mathrm{Al}$ Arif et al. (2017), among others, is (1) to increase the growth of the Islamic banking industry so that it can make a significant contribution to the Indonesian economy, (2) to increase the independence of bank subsidiaries, (3) to improve the performance of the spin-off bank and (4) to increase the Islamic banks' compliance with Islamic principles.

Although it has many challenges, one of the pieces of evidence found is that the spin-off policy has good benefits for the growth of Third Party Funds in Indonesian Islamic banking (Arif, 2014). Research on the spin-off of Islamic windows in banking also found some disadvantages, including the conversion strategy that produces better results, especially for profitability and efficiency, compared to the pure spin-off strategy (Trinugroho et al., 2020).

The spin-off decision made by Islamic banking aims to develop the industry, both on a national and international scale. However, the increase in the number of Islamic banks due to spin-offs did not result in the bank's performance 
(in terms of efficiency), increasing Al Arif et al. (2018), which was further strengthened in the research of Al Arif et al. (2020). Then it is known that the more considerable capital will improve the average performance (Prasetyo et al., 2019). However, Fahmi \& Septiarini (2020) found that the decline in financial performance (CAR, NPF, and FDR) was not caused by the bank's spin-off

\section{METHODOLOGY}

This study is exploratory research where the research area, namely spinoffs on Islamic finance companies, is very new or very vague due to the lack of research on this matter (Cooper \& Schindler, 2014). So it is necessary to do exploration to study spin-off decision making. Essential variables that exist in exploratory research included in this study are not yet fully known or defined. The statistical method used is nonparametric for ordinal data. This test does not require any assumptions about the shape of the population distribution. This test requires that the variables in the data can be sorted and ranked. Variables must be measured on an ordinal, interval, or ratio scale (Lind et al., 2018).

To answer the research questions, the stages used in this research are Stage 1 , determining the factors that influence the decision-making of the Islamic windows Financing Company spin-off. Conclusions on the criteria begin with deciding the initial criteria based on previous research regarding the company's spin-off decision making. The proposed measures are then assessed by 2 (two) experts in the Islamic Financing Company before being made in the form of a questionnaire. Stage 2, analysis of financing company Islamic windows spin-off decision making. Further analysis of the criteria used in the spin-off decision was carried out using the Analytical Hierarchy Process (AHP). The AHP method in this study is because, as a preliminary study, more types of qualitative data will be used. The AHP method will convert the qualitative data into quantitative data. Stage 3, the ranking criteria generated from the AHP method, will be discussed based on previous research and reconfirmation with the respondents.

The assessment using the AHP method is determined by the Expert in the field of Islamic Financing Companies. Experts are selected based on their knowledge and experience in finance companies, both as practitioners and regulators. Practitioners must meet the requirements as a spin-off strategy decision-maker in finance companies, namely at the minimum level of Director.

Table 1. Expert panel for AHP

\begin{tabular}{lcc}
\hline \multicolumn{1}{c}{ Panel Expert } & Number of People & Background \\
\hline Regulator & 1 & OJK \\
\hline Practitioner & 12 & Financing Company \\
\hline Total & 13 & \\
\hline
\end{tabular}

This study uses primary and secondary data, both of which will be combined to answer research questions. Primary Data is data that comes from the source or the first party. Primary data was obtained from a questionnaire to experts who assessed the pairwise comparison matrix built. Preliminary 
information is also obtained from in-depth interviews with competent sources to construct a hierarchy used in making a pairwise comparison matrix. Secondary data from this research can be in reports issued by OJK, the internet, and other literature studies.

\section{RESULTS}

\section{Factors Affecting Spin-Off Decision Of Islamic Windows Of Financing Companies}

The hierarchical arrangement of spin-offs is carried out based on literature studies and interviews with informants regarding their, first, human resources (Leitner et al., 2021), short-term benefits, possible risks, and synergies within the company (Pizarro-Moreno et al., 2021), integrated information (Esch et al., 2019), independent operation through information technology and product development (Li et al., 2020); Second, business plans, the attention of shareholders and decision-makers, and strategies (Roosmawati, 2021).

A decision-making hierarchy is formed by looking at all the criteria studied previously and considering the development of Islamic finance companies, as shown in Figure 1. It should be noted that AHP pays attention to the consistency of respondents' decision-making. It is highly recommended to reduce the criteria chosen by the respondents. For this reason, this grouping in the established hierarchy considers the similarity of functions needed in decision making.

The explanation of the hierarchy in making the spin-off decision is as follows:

1. Non-financial support, abbreviated as NF, is the company's internal condition to support Islamic windows operations which consists of:

a. Human resource support, abbreviated as HR, is information about the background, experience, track record, and various skills/functions of the human resources owned by Islamic windows or parent HR that Islamic windows can use.

b. IT support, abbreviated as IT, is Information Technology (IT) support for Islamic windows operations, including Islamic windows independence in managing IT.

2. The attention of shareholders/directors (Management Attention), abbreviated as MA, is information on the partisanship of shareholders/directors for the development of Islamic financing as well as clarity of business concepts and strategies in the development of Islamic financing, which consists of:

a. Attention to the development of Islamic finance (Attention), abbreviated as ATT, namely the attention or partiality shown by the shareholders/directors in the development of Islamic financing

b. The concept and strategy of the Islamic financing business (Business Plan), abbreviated as BP, was created by the shareholders/directors, which later became the operational basis of the Islamic windows

3. The financial condition of Islamic windows, abbreviated as FC, is information about the financial situation of Islamic windows, which consists of: 
a. Assets, abbreviated as A, are information on assets owned by Islamic windows. There are 2 (two) forms of communication needed, namely:

i. The portion of Islamic windows assets to parent assets (market share), abbreviated as MS, is divided by parent assets.

ii. Total assets, abbreviated as TA, are the total assets owned by Islamic windows.

b. Rate of return, abbreviated as RR, is the condition of the company's investment rate of return in Islamic windows

c. Cost structure, abbreviated as CS, namely the condition of the Islamic windows cost structure and information regarding the independence of charging fees made by the parent to Islamic windows

4. Market, abbreviated as $\mathrm{M}$, is external information regarding the condition of the Islamic financing market, which consists of:

a. Market growth and potential (growth), abbreviated as G, is information regarding the growth conditions of the Islamic finance industry market and the potential of the market in the future.

b. The level of competition, abbreviated as LC, is a condition of competition between companies in the financing market

c. A typical product, abbreviated as $\mathrm{P}$, is an Islamic financing product owned only by Islamic financing

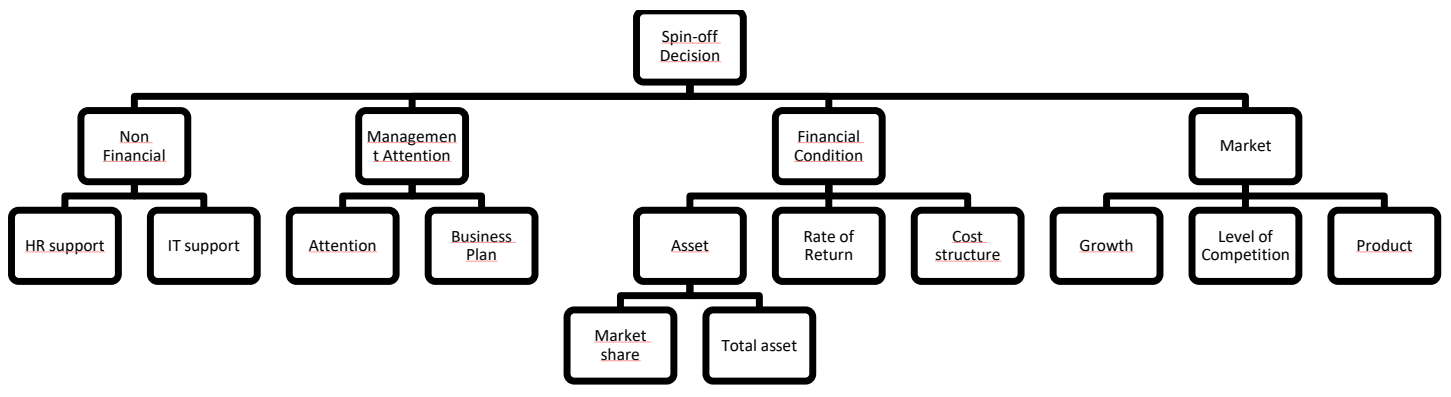

Figure 1. Hierarchy of Decision Making Criteria in Islamic Windows spin-off

\section{The Analytical Hierarchy Process Result}

that have been arranged in the hierarchy in Figure 1 are then made a pairwise comparison. The respondents then assessed the comparison in a questionnaire by giving weight to each comparison using the Saaty Scale and then compiled in a pairwise comparison matrix. Before being included in the matrix, each respondent's answer was first checked for consistency. In the first test, it was found that 8 out of 13 respondents did not meet the test with a Consistency Ratio (CR) exceeding 0.1. Saaty (2013) suggested that if the ratio exceeds 0.1 , the set of ratings may be highly inconsistent to be reliable. It reconfirmed the respondents to improve the answers given so that the consistency of the responses was below the test threshold. By reconfirming, respondents can review their answers so that consistency can be improved. From 
the results of the reconfirmation, all respondents met the test with a Consistency Ratio (CR) of less than 0.1 .

All incoming data is then compiled using the Geomean average to return the geometric mean of all the data in question. The data gathered in the pairwise comparison matrix for the spin-off criteria can be seen in Appendix 1. From the data, it can be seen that the weights of the bars are distributed normally, and no measure has a dominating weight (more than $75 \%$ ) or criteria that are not has a weight $(0 \%)$. The ranking of the requirements is done based on the weights obtained from the pairwise comparison matrix. For the spin-off decision-making criteria, the financial condition becomes the criterion that has the most significant weight, followed by the attention of shareholders, then the Islamic financing market, and finally non-financial support (Table 2).

Table 2. Spin-Off Decision Making Criteria Ranking

\begin{tabular}{c|cc}
\hline Criteria & Weight & Ranking \\
\hline Financial Condition & 0.365 & 1 \\
Management Attention & 0.254 & 2 \\
Market & 0.227 & 3 \\
Non Financial Condition & 0.155 & 4 \\
\hline
\end{tabular}

Furthermore, in each criterion matrix, a ranking is determined to describe the priority in the sub-criteria contained in it (Table 3).

Table 3. Local Rating for Criteria

\begin{tabular}{l|lcc}
\hline Criteria & Sub-criteria & Local weight & Ranking \\
\hline Non & Human Resource & 0.667 & 1 \\
Financial & Information Technology & 0.333 & 2 \\
\hline Management & Business Plan & 0.562 & 1 \\
Attention & Attention & 0.438 & 2 \\
\hline \multirow{2}{*}{ Financial } & Cost Structure & 0.386 & 1 \\
Condition & Rate of Return & 0.362 & 2 \\
& Asset & 0.252 & 3 \\
\hline \multirow{3}{*}{ Market } & Growth & 0.469 & 1 \\
& Product & 0.401 & 2 \\
& Level of Competition & 0.131 & 3 \\
\multirow{2}{*}{ Asset } & Market Share & 0.548 & 1 \\
& Total Asset & 0.452 & 2 \\
\hline
\end{tabular}

Then, each sub-criteria is sorted by local weight and criterion weight to form a global ranking (Table 4). This rating can be used to determine the extent to which each sub-criteria influences the decision to spin-off the Islamic windows of a Financing Company. 
Table 4. Global Ranking

\begin{tabular}{l|cc}
\hline Sub-criteria & Global weight & Ranking \\
\hline Business Plan & 0.143 & 1 \\
Cost Structure & 0.141 & 2 \\
Rate of Return & 0.132 & 3 \\
Attention & 0.111 & 4 \\
Growth & 0.106 & 5 \\
Human Resource & 0.103 & 6 \\
Product & 0.091 & 7 \\
Information Technology & 0.052 & 8 \\
Market Share & 0.050 & 9 \\
Total Asset & 0.042 & 10 \\
Level of Competition & 0.030 & 11 \\
\hline
\end{tabular}

In the global rankings, the concept and strategy of the Islamic financing business is the most crucial concern in making spin-off decisions, followed by the cost structure and rate of return of Islamic windows. The level of competition is the sub-criteria that has the lowest priority ranking.

\section{Result Analysis}

From the results of the analysis using AHP, it can be seen that the main criteria that have the most influence are financial conditions (0.365) followed by the attention of shareholders/directors (0.254), then the Islamic financing market $(0.227)$, and finally non-financial support (0.155). Financial condition is ranked first in the criteria to be considered in making spin-off decisions. The data supporting this criterion is the fastest known data for spin-off decision-makers. The Board of Directors and Shareholders can first assess Islamic windows readiness from this data. Regulators can also supervise to improve the quality of Islamic windows' financial condition within the framework of accelerating spinoffs.

Human resources must be prioritized over IT. Meanwhile, on the criteria for the attention of shareholders/directors, the sub-criteria for business strategy is more prioritized than the attention for the development of Islamic finance. However, the weight of the difference between the two is not too much different. The cost structure is the highest priority in the criteria of financial condition. As for the requirements for the Islamic financing market, market growth is the essential sub-criteria. As for the Islamic windows asset sub-criteria, decisionmakers choose Islamic windows market share to be more important than total assets, even though both have almost the same weight.

Meanwhile, based on the global ranking, it can be seen that the concept and strategy of the Islamic financing business is the highest priority (0.143), then the cost structure (0.141) and the return on investment (0.132). The sub-criteria with the lowest ranking is the level of competition (0.030), then total assets (0.042), and 
market share (0.050). The weight of the criteria and sub-criteria can assess the Islamic windows ready for a spin-off. A spin-off can be decided by analysis:

Table 5. Spin-off Decision Analysis

\begin{tabular}{|c|c|c|}
\hline 1. & Using criteria & $\begin{array}{l}0.365 \text { (Financial Condition) }+0.254 \text { (Management } \\
\text { Attention) }+0.227 \text { (Market) }+0.155 \text { (Non Financial } \\
\text { Condition) }\end{array}$ \\
\hline 2. & $\begin{array}{l}\text { Using criteria } \\
\text { locally }\end{array}$ & $\begin{array}{l}0.365(0.386 \text { (Cost Structure) }+0.362 \text { (Rate of Return) }+ \\
0.252(0.548 \text { (Market Share) }+0.452 \text { (Total Asset) }))+ \\
0.254(0.562 \text { (Business Plan) }+0.438 \text { (Attention) })+0.227 \\
(0.469 \text { (Growth) }+0.401 \text { (Product) }+0.131 \text { (Level of } \\
\text { Competition) })+0.155(0.667 \text { (Human Resource) }+0.333 \\
(\text { Information Technology) })\end{array}$ \\
\hline 3. & $\begin{array}{l}\text { Using sub- } \\
\text { criteria } \\
\text { globally }\end{array}$ & $\begin{array}{l}0.143 \text { (Business Plan) }+0.141 \text { (Cost Structure) }+0.132 \\
(\text { Rate of Return) }+0 . \text { Islamic windows (Attention) }+ \\
0.106 \text { (Growth) }+0.103 \text { (Human Resource) }+0.091 \\
(\text { Product })+0.052 \text { (Information Technology) }+0.050 \\
\text { (Market Share) }+0.042 \text { (Total Asset) }+0.030 \text { (Level of } \\
\text { Competition) }\end{array}$ \\
\hline
\end{tabular}

\section{DISCUSSION}

As the first rank, the concept and strategy of Islamic financing business made by shareholders/directors are relevant to be the primary concern in deciding whether the Islamic window is ready to be a spin-off. These business concepts and strategies are mainly contained in the Islamic windows business plan. In the business plan, we will find out the short-term and long-term targets targeted by Islamic windows and how to achieve these targets. The business plan can be assessed by internal companies and by external companies such as regulators and investors. The seriousness of the management in making the Islamic windows business plan is taking into account the company's strengths and future potential. The assistance of regulators as supervisors of financing companies in preparing and implementing Islamic windows business plans can make Islamic windows more prepared to carry out its business strategies, including preparing them for a spin-off.

The cost structure is the second priority in the sub-criteria that is considered in the spin-off decision making. This factor was also observed with Al Arif et al. (2020), which shows that although one of the objectives of the spin-off is to increase efficiency, this is not found in the bank's performance after the result due to the increasing cost structure. For this reason, regulators need to support spin-off policies that allow spin-off companies to continue using facilities or systems from the parent company so that the cost structure does not increase sharply after the spin-off is carried out.

The condition of the company's return on investment in Islamic windows is ranked third in the sub-criteria chosen by the spin-off decision-makers in the 
Financing Company. If it is returned to the spin-off definition presented by DePamphilis (2019), this strategic decision is closely related to profit sharing in investments to subsidiaries. For this reason, company management must pay attention to the data on the rate of return on investment before deciding on a spin-off and their expectations if the spin-off will be implemented.

Discussion on the assessment used on the criteria and sub-criteria for determining the decision must also be considered. Assessment of non-financial support for human resources is carried out by considering the quantity possessed by the Islamic window and its quality to support its function as a company. The importance of human resources is considered in the research of Furlan \& Grandinetti (2014). The fulfillment of the minimum tasks that a finance company must own can be seen by using a list of organizational functions that are imposed in the regulations regarding sharia finance companies. As in the preparation stage for the spin-off, the human resources owned by Islamic Window do not have concurrent duties with the parent company. So that when the spin-off is carried out, the new company already has human resources who have sufficient experience to carry out their duties without assistance from the parent company.

Assessment of information technology leads to the independence of information technology systems and the efforts made by the parent company to prepare for it. The appraisal must pay attention to the fulfillment of a list of minimum requirements regarding information technology that Islamic finance companies must consider according to applicable regulations. This regulation includes having standard operating procedures related to business activities by utilizing information technology. It also needs human resources who have the expertise and background in information technology. Information technology also requires a data center and disaster recovery center located in Indonesia and has a reliable and secure information system. Efforts to achieve independence can be assessed by observing the Islamic window information and technology roadmap or in the company's business plan in developing the Islamic window.

The assessment of non-financial support pays more attention to the results in the evaluation of human resources and information technology, as stated by the respondents. Decision-makers can also pay attention to other things within the company's internal scope and outside of financial factors.

The assessment of the attention to the development of sharia finance considers the quantity and quality of decision-making made by shareholders/directors in the context of developing sharia financing. In POJK Number 10 of 2019, it is stated that Islamic financing companies are required to form a product and development committee for sharia business activities. In companies with an Islamic window, the committee is chaired by the head of the Islamic window. The follow-up to the implementation of the committee's duties is not discussed in the regulation. This lag is where it can be seen how the alignments of the directors and shareholders on the development of sharia financing can be seen. Directors and shareholders who are considered good provide input and pay attention to the results of the committee's work. Assessment attention can be made by considering the quantity and quality of 
feedback and follow-up from the board of directors and shareholders on the results of the product committee and the development of the Islamic window.

The assessment of the concept and strategy of sharia financing business considers the Islamic window business plan for one year, medium-term and long term. SEOJK Number 23/SEOJK.05/2019 concerning Business Plans for Financing Companies and Sharia Financing Companies regulates the scope of the business plan, the form and structure of the business plan realization report, the form and structure of the business plan supervision report, and procedures for submitting a business plan, adjusting the plan. Business plans, changes to business plans, information on the realization of business plans, and reports on supervision of business plans for financing companies and sharia finance companies. This arrangement is only for business plans with a period of 1 year. In this regulation, the Islamic window business plan is an integral part of the parent company's business plan. The assessment of this sub-criteria pays attention to the planning, realization, and supervision of Islamic window activities. A business plan that is considered reasonable is an active business plan that contains all of these sections to show the movement of Islamic window activities. The biggest challenge is assessing the company's preparation for a spin-off. This challenge is because the practice is in the mid-term and long-term business plans. However, this can be replaced by considering the development of other criteria and sub-criteria from year to year. Assessors can also use the characteristics of the Islamic window that is ready for a spin-off.

The assessment of the attention of shareholders/directors as a whole is very concerned with the results of the evaluation on the awareness of sharia finance development and sharia financing business concepts and strategies. Decisionmakers can also pay attention to changes in business strategy made due to changes in directors/shareholders.

The assessment of the criteria for the financial condition of the Islamic window can be done by taking into account the financial statements of the Islamic window, the financial projection report of the Islamic window, and the audit report of the parent company. This is in line with the research of Pambuko (2019) and Trinugroho et al. (2020). The financial condition criteria and sub-criteria are then mapped out their development, compared to peers and the industry as a whole.

Market criteria and sub-criteria in it is an assessment of the situation outside the company. This criterion must also measure the potential and future challenges that the company and the industry will face. For this reason, the data required for this assessment consists of the company's data, peer companies, and industry data. Respondents pay attention to these criteria, primarily to determine the direction of the Islamic window strategy.

\section{CONCLUSION}

Financing companies can voluntarily carry out spin-offs for their Islamic windows. Some factors influence spin-off decision-making. This study finds that the spin-off decision making is influenced by the Islamic window financial 
condition criteria, attention of shareholders/Directors, Islamic financing market, and non-financial support. Financial condition is an essential criterion considered in making decisions, mainly to signal the condition of the Islamic window. The sub-criteria that are considered in making the spin-off decision are (1) HR support, (2) IT support, (3) attention to Islamic finance development, (4) Sharia financing business concepts and strategies, (5) asset portion, (6) total assets, (7) rate of return, (8) cost structure, (9) growth and market potential, (10) level of competition, and (11) distinctive products. Business concepts and strategies, cost structure, and rate of return on investment are the highest priority decision-makers should consider sub-criteria. Furthermore, the weights on the criteria and sub-criteria can assess the Islamic window ready for a spin-off.

This study implies that spin-offs can be decided by analysis using criteria, a combination of measures and sub-criteria locally, or using sub-criteria globally, resulting in several proposals for future concerns. The Board of Directors can assess the readiness of the company's Islamic windows by considering the criteria for the financial condition, shareholders/directors' attention, then the Islamic financing market, and finally, non-financial support. The Board of Directors and Shareholders can provide a first view in assessing the readiness of Islamic windows by looking at the financial condition of Islamic windows. Management must be serious in making the Islamic windows business plan by considering the company's strengths and future potential. Company management should pay attention to the return-on-investment data before deciding on a spin-off and their expectations if the spin-off will be implemented.

Regulators can assess the readiness of the company's Islamic windows by considering the criteria for financial conditions, shareholders/directors' attention, then the Islamic financing market, and non-financial support. They can compare the readiness of an Islamic window with other Islamic windows so that it is known which Islamic windows is a priority for a spin-off. They must conduct supervision to improve financial condition quality within the framework of accelerating spin-offs. Finally, they assist in preparing and implementing Islamic windows business plans so that Islamic windows are better prepared for a spinoff. Regulators need to make spin-off policies that allow spin-off companies to continue to use facilities or systems from the parent company so that the cost structure does not increase sharply after the spin-off is carried out.

\section{FURTHER STUDY}

This study only identifies factors and how much influence these factors have in making spin-off decisions. Further research in this area should determine (a) the spin-off readiness of each Islamic window of a Financing Company by considering these factors, (b) the different possible interactions between all the factors which moderate the decision to a spin-off, and (c) decision making in other financial institutions, such as takaful, credit guarantee company, and fintech. 


\section{REFERENCES}

Aggarwal, P., \& Garg, S. (2019). Restructuring through spin-off: impact on shareholder wealth TT - Restructuring through spin-off. Managerial Finance, 45(10/11), 1458-1468. https://doi.org/http://dx.doi.org/10.1108/MF-112017-0487

Al Arif, M. N. R. (2017). Spin-off and market share in the Indonesian Islamic banking industry: A difference in difference analysis. Management and Marketing. https:/ / doi.org/10.1515/mmcks-2017-0032

Al Arif, M. N. R. (2018). Does the spin-off policy can accelerate the deposit funds in the Indonesian Islamic banking industry? Journal of Business and Retail Management Research, 13(1), 171-178. https:// doi.org/10.24052/JBRMR/V13IS01/ART-17

Al Arif, M. N. R., Haribowo, I., \& Suherlan, A. (2018). Spin-off policy and efficiency in the Indonesian Islamic banking industry. In Banks and Bank Systems (Vol. 13, Issue 1, pp. 1-10). LLC CPC Business Perspectives. https:// doi.org/10.21511/bbs.13(1).2018.01

Al Arif, M. N. R., Mufraini, M. A., \& Prabowo, M. A. (2020). Market Structure, Spin-Off, and Efficiency: Evidence from Indonesian Islamic Banking Industry. Emerging Markets Finance and Trade, 56(2), 329-337. https:/ / doi.org/10.1080/1540496X.2018.1553162

Al Arif, M. N. R., Nachrowi, N. D., Nasution, M. E., \& Mahmud, T. M. Z. (2017). The Islamic banking spin-off: Lessons from Indonesian Islamic banking experiences. Journal of King Abdulaziz University, Islamic Economics, 30(2), 117-133. https://doi.org/10.4197/Islec.30-2.11

Al Hosani, Y., \& Jabeen, F. (2019). Barriers in post-merger integration in the real estate development companies in the United Arab Emirates: An AHP approach. Polish Journal of Management Studies, 19(2), 33-47. https:// doi.org/10.17512/pjms.2019.19.2.03

Arif, M. N. R. Al. (2014). Spin-off and its impact on the third party funds of Indonesian Islamic banking industry. Economic Journal of Emerging Markets. https:// doi.org/10.20885/ejem.vol6.iss1.art5

Bennett, V. M., \& Feldman, E. R. (2017). Make room! Make room! A note on sequential spin-offs and acquisitions. Strategy Science, 2(2), 100-110. https:/ / doi.org/10.1287/stsc.2017.0030

Cevik Onar, S., Oztaysi, B., \& Kahraman, C. (2014). Strategic Decision Selection Using Hesitant fuzzy TOPSIS and Interval Type-2 Fuzzy AHP: A case study. International Journal of Computational Intelligence Systems, 7(5), 1002-1021. https:// doi.org/10.1080/18756891.2014.964011

Chu, P., Teng, M., Lee, C., \& Chiu, H. (2010). Spin-off strategies and performance : A case study of Taiwan's s Acer group. Asian Business \& Management, 9(1), 101-125. https://doi.org/10.1057/abm.2009.24

Cooper, D. R., \& Schindler, P. S. (2014). Research Design: An Overview. In Business Research Methods (12th ed., p. 129). McGraw-Hill/Irwin.

DePamphilis, D. M. (2019). Mergers, acquisitions, and other restructuring activities: An integrated approach to process, tools, cases, and solutions. In 
Mergers, Acquisitions, and Other Restructuring Activities: An Integrated Approach to Process, Tools, Cases, and Solutions. https:// doi.org/10.1016/C2017-0-02823-9

Esch, M., Schnellbächer, B., \& Wald, A. (2019). Does integrated reporting information influence internal decision making? An experimental study of investment behavior. Business Strategy and the Environment, 28(4), 599-610. https:// doi.org/10.1002/bse.2267

Fahmi, M., \& Septiarini, D. F. (2020). Does the spin-off policy change the shariah bank financial ratio? Opcion, 36(Special Edition 27), 1447-1463. https://www.scopus.com/inward/ record.uri?eid=2-s2.085085015701\&partnerID $=40 \& m d 5=300 \mathrm{e} 40 \mathrm{ab3e} 0668741 \mathrm{~b} 2 \mathrm{eca} 6041 \mathrm{df} 367 \mathrm{~d}$

Fernando, A. (2018). Tunggu kebijakan OJK soal spin off, kinerja pembiayaan syariah melorot.

Keuangan.Kontan.Co.Id. https:/ / keuangan.kontan.co.id/news/tunggu-kebijakan-ojk-soal-spin-offkinerja-pembiayaan-syariah-melorot

Furlan, A., \& Grandinetti, R. (2014). Spin-off performance in the start-up phase a conceptual framework. Journal of Small Business and Enterprise Development, 21(3), 528-544. https://doi.org/10.1108/JSBED-04-2014-0055

Ito, K. (1995). Japanese spin-offs: Unexplored survival strategies. Strategic Management Journal. https:/ / doi.org/10.1002/smj.4250160603

Kim, S., \& Oh, J. (2020). Macroeconomic effects of macroprudential policies: Evidence from LTV and DTI policies in Korea. Japan and the World Economy, 53, 100997. https://doi.org/https://doi.org/10.1016/j.japwor.2020.100997

Leitner, K.-H., Bergner, S., \& Rybnicek, R. (2021). The role of heads of departments in the commercialization of university research. Journal of Business Economics, 91(3), 353-378. https://doi.org/10.1007/s11573-02001003-y

Li, Z., He, S., Ning, J., Liu, Z., Zhang, J., \& Du, X. (2020). Business model transfer mechanism: A study about spin-off entrepreneurship based on the grounded theory. Nankai Business Review International, 11(1), 44-68. https://doi.org/http://dx.doi.org/10.1108/NBRI-06-2019-0021

Liang, Q., \& Hu, H. (2020). Study on Identification of Spurious Public-Private Partnership Projects in China. IEEE Transactions on Engineering Management, 67(2), 376-384. https://doi.org/10.1109/TEM.2018.2877261

Lind, D. A., Marchal, W. G., \& Wathen, S. A. (2018). Non Parametric Methods: Analysis of Ordinal Data. In Statistical Techniques in Business \& Economics (7th edition, p. 582). McGraw-Hill Education.

Liu, K. (2020). Chinese consumer finance: a primer. Frontiers of Business Research in China, 14(1). https:// doi.org/10.1186/ s11782-020-00077-3

Otoritas Jasa Keuangan. (2021). Master Plan Sektor Jasa Keuangan Indonesia 20212025.

https:// www.ojk.go.id/id/berita-dankegiatan/publikasi/Documents/Pages/Master-Plan-Sektor-JasaKeuangan-Indonesia-2021-2025/Master Plan Sektor Jasa Keuangan Indonesia 2021-2025.pdf

Pambuko, Z. B. (2019). Kebijakan Spin-off dan Efisiensi Perbankan Syariah di 
Indonesia. Ihtifaz: Journal of Islamic Economics, Finance, and Banking. https:/ / doi.org/10.12928/ijiefb.v2i1.822

Pizarro-Moreno, M. I., De Castro, J., Galán González, J. L., \& Palacios-Florencio, B. (2021). Breaking down the decision to externalise new corporate ventures. Total Quality Management and Business Excellence, 32(1-2). https:/ / doi.org/10.1080/14783363.2018.1530592

Prasetyo, M. B., Luxianto, R., Baskoro, R. A., Adawiyah, W., Putri, N. I. S., \& Spinoffs, B. (2019). The Role of Capital on Islamic Bank Spin-Offs in Indonesia Capital on Islamic. 13(2), 119-139. https:/ / search.proquest.com/docview/2354884888?accountid=17242

Rogers, E. M., Takegami, S., \& Yin, J. (2001). Lessons learned about technology transfer. Technovation, 21(4), 253-261. https://doi.org/10.1016/S01664972(00)00039-0

Rothaermel, F. (2017). Corporate Strategy: Vertical Integration and Diversification. In Strategic Management (Third edit, p. 255). McGraw-Hill Education.

Saaty, T. L. (2013). The modern science of multi-criteria decision making and its practical applications: The AHP/ANP approach. Operations Research, 61(5), 1101-1118. https://doi.org/10.1287/opre.2013.1197

Sari, F. (2019). Penyaluran pembiayaan syariah multifinance seret. Keuangan.Kontan.Co.Id.

https:// keuangan.kontan.co.id/news/penyaluran-pembiayaan-syariahmultifinance-seret

Soemitra, A. (2017). Lembaga Pembiayaan Syariah. In Bank dan Lembaga Keuangan Syariah (2nd ed., p. 349). Prenada Media.

Trinugroho, I., Santoso, W., Irawanto, R., \& Pamungkas, P. (2020). Is spin-off policy an effective way to improve performance of Islamic banks? Evidence from Indonesia. Research in International Business and Finance. https:// doi.org/10.1016/j.ribaf.2020.101352

Vovchenko, N. G., Alukhanyan, A. A., Andreeva, L. Y., \& Buryakov, G. A. (2018). Formation of an Adaptive Personnel Training System as a Factor of Ensuring Financial Stability of Leasing Companies. European Research Studies Journal, 21, 3-15. https://doi.org/10.35808/ersj/1153 